\title{
Sustainable Development and Environmental Sustainability in Large-Scale Retailers
}

\author{
Sabina Riboldazzi *
}

\begin{abstract}
Mounting pressures from society demanding higher standards in business ethics, along with a growing number of consumers and several other market players sensitive to issues concerning corporate social responsibility and sustainable development, have encouraged the adoption of new behaviors by those large-scale retailers seeking to achieve positive business results through economic effectiveness and efficiency while respecting human rights, social balance, and the environment. The present study, through in-depth analysis of business practices of major domestic large-scale retailers, aims to assess, in the context of economic, social, and environmental responsibilities, the various initiatives developed by such retailers with respect to environmental protection.
\end{abstract}

Keywords: Large-Scale Retailers; Environmental Sustainability; Corporate Sustainability; Sustainable Development; Global Markets

\section{Corporate Social Responsibility and Corporate Sustainability}

Globalization, alongside a series of other factors such as government demands, information availability, and consumer interest, has led companies to develop and implement corporate policies dealing with corporate social responsibility and sustainable development.

The first comprehensive discussion of corporate social responsibility (CSR) was first published in a book by Howard R. Bowen entitled "Social Responsibilities of the Businessman", where the author emphasized the importance of taking into account not only the economic outcome but also its social impact.

Based on Bowen's seminal studies, a number of theoretical works have then further developed the broad concept of CSR, often finding analogies with other substantially similar concepts or terms that, for the most part, only differ from the former because of the emphasis given to certain elements rather than others (Perrini, Pogutz \& Tencati, 2006a, 2006b). These complementary concepts include: business philanthropy and charity, business ethics, corporate social responsiveness, corporate social performance, corporate social rectitude, sustainable development, triple bottom line, and corporate citizenship (Ackerman, 1973; Bowen, 1953; Carrol, 1979, 1991, 1998, 1999, 2000; Davis, 1967, 1975; Davis \& Blomstorm,

\footnotetext{
* Assistant Professor of Management, University of Milano - Bicocca (sabina.riboldazzi@unimib.it) 
1966; Eilbirt \& Parket, 1973; Elkington, 1997; Frederick, 1960, 1986, 1994, 1998; Freeman, 1984, 2010; Healdm, 1957; Henderson, 1968; Johnson, 1971; Jones, 1980; Mc Guire, 1963; Sethi 1975; Steiner, 1971).

A definition that best represents the concept of CSR can be found in the European Commission's Green Paper, according to which CSR is based on the voluntary integration of social and environmental concerns in all business operations and stakeholder interactions of an enterprise. In brief, CSR refers to the commitment to behave in a correct way, which goes beyond compliance with the obligations set by laws and individual ethical standards. CSR is therefore a behavior that should influence all areas of governance and business management. In this regard, the evolving concept of CSR has been recently likened to that of corporate sustainability (Keijzers, 2002).

Corporate sustainability concerns companies that, during the organization of their activities over the long-term, establish positive relationships with their stakeholders while pursuing their objectives in line with the concept of sustainable development, which aims to meet the needs of the present allowing future generations to meet their own. In particular, those enterprises that embark on the path of sustainable development are those that implement their strategies complying with three fundamental conditions: 1) creation of economic value for themselves and the community (i.e. economic sustainability); 2) care for the environment through careful evaluation of the environmental impact of all processes, products, and services developed by the company (i.e. environmental sustainability); and 3) satisfaction of social actors, that is to say the ability of the enterprise to ensure, in a fair way, conditions of human well-being (i.e. social sustainability) (Riboldazzi, 2016).

The number of enterprises planning their strategies with a focus on sustainable development is becoming increasingly higher. In particular, large-scale retailers, often operating as leaders in marketing channels and placing themselves in the final phase of the supply chain, are often promoters of sustainable policies involving all actors in the supply chain and the marketing channels thanks to their liaison role with environmentally conscious consumers.

The present study aims to address the issue of sustainable development and corporate sustainability in large-scale retailers by analyzing their economic, social, and environmental sustainability policies. Furthermore, our survey takes a closer look to the various environmental sustainability initiatives adopted by the main Italian large-scale retailers. For this purpose, secondary data were analyzed (e.g. websites and annual reports of large-scale retailers, business sector reports, and specialized magazines) concerning the business activities of the top ten companies operating in the Italian large-scale retail market [i.e. Coop Italia, Conad, Selex, Esselunga, Auchan, Carrefour, Eurospin, Vege, Pam and Finiper]. Lastly, the environmental sustainability initiatives of the Carrefour Group, which is second in the world and the first in Europe in terms of revenues, were similarly analyzed. 


\section{Sustainable Development in Large-Scale Retailers}

Pressures coming from society demanding higher standards in business ethics, legislative initiatives supporting sustainable development programs, and the growing number of consumers and other market players increasingly conscious about issues related to corporate social responsibility and sustainable development, have fueled the implementation of new policies in those large-scale retailers aiming to achieve positive business results through economic effectiveness and efficiency while respecting human rights, social balance, and the environment.

The main activity of large-scale retailers is to produce and sell commercial services that allow products to be transferred along a path that starts in the warehouse of the manufacturer and ends on the shelves of the point of sale managed by the distributor itself.

In other words, distributors make available to potential customers the goods they intend to buy by reducing spatial, temporal, quantitative, and qualitative gaps existing between supply and demand, thus placing themselves at the forefront of the customer experience. Inevitably, these retailers, in order to qualify and develop market offerings able to fulfill customer and market expectations, are obliged to implement business policies able to match the growing demand for greater sustainability from the society as a whole. Indeed, in-depth analysis of the business activities of top ranking global [e.g. Wal-Mart Stores Inc, Costco Wholesale Corporation, The Kroger Co., Schwarz Unternehmenstreuhand KG, Carrefour S.A., Aldi Einkauf GmbH \& Co., Tesco PLC, Target Corporation, Metro Ag, Aeon Co. Ltd., Auchan Holding SA, Albertsons Companies Inc, Edeka Group, Casino Guichard-Perrachon S.A., Seven \& i Holdings Co. Ltd.] (Deloitte, 2017) or domestic [Coop Italia, Conad, Selex, Esselunga, Auchan, Carrefour, Eurospin, Vege, Pam, Finiper] (Conad, 2015) large-scale retailers reveals a strong willingness to address themes of corporate sustainability and sustainable development, exemplified by management, organizational, and technological changes aimed at implementing strategies and practices oriented towards sustainability.

The issues of corporate sustainability and sustainable development in large-scale retailers can be better understood when we consider the policies and behaviors of these retailers regarding the three dimensions of sustainability (i.e. profit, people, and planet) (Elkington, 1997), which can be linked to the following concepts: 1) economic sustainability, that is the ability to generate income and economic value; 2) social sustainability, that is the ability to guarantee conditions of human wellbeing, safety, health, and education, all equally distributed among classes and gender; and 3) environmental sustainability, that is the ability to maintain the quality and renewability of natural resources.

Starting from the economic dimension, the ability to generate profit and value in retailing is tightly linked to the capability of developing, according to the principles of effectiveness and efficiency, competitive market offerings able to meet the rapidly changing needs of consumers. In this regard, large-scale retailers usually adopt a market-driven orientation, which allows them to modify their activities according to sudden market changes and opportunities.

In particular, the development of retailer companies is often the result of different corporate strategies such as horizontal or vertical integration and diversification (Riboldazzi, 2015). 
Horizontal integration refers to the acquisition of competitors, or other points of sale, to strengthen the company's competitive position; vertical integration is achieved when the retailer gains control of additional stages of the marketing channel (e.g. wholesale stage). Finally, diversification derives from an expansion of commercial activities related to new products targeted to new markets.

Therefore, large-scale retailers pursue profits by managing numerous stores often belonging to different distribution formats (i.e. multichannel strategy) and identified by various store brands. Consequently, supermarkets, hypermarkets, convenience stores, discount stores, and specialty stores are managed and coordinated by big retailers to meet customer needs and maintain a balanced position, at the corporate level, in terms of turnover and profitability.

Over the past decade, many retailers have also developed online sales to exploit the opportunities offered by internet and other new technologies. By new technologies, we refer to the introduction of self-scanning, personal shopping assistant, electronic shelf label, RFID, virtual supermarkets, virtual shoppers, etc. The goal is to improve the commercial offer and create value for consumers and for the company.

The ability to generate profit and value can also be achieved by improving operational efficiency, which involves the logistics, transport, and storage functions, the qualitative and quantitative adaptation of lots of goods, the provision of pre, during, and after sale services, and all the information and communication functions. Efficiency is often linked to the ability of retailers to manage a complex and articulated system of competitive strategic alliances. Sure enough, numerous operations such as outsourcing, R\&D partnership, licensing, cooperative marketing, and so on, are coordinated and managed so as to take advantage of the expertise, skills, and know-how of different partners, which help minimize costs thanks to economies of scope and specialization.

Finally, profit is often achieved through innovation of the commercial offer in terms of format and products or services offered at the point of sale. In this regard, innovation involves the retailing mix levers and refers to a dynamic management of assortments, private label, price, merchandising, and communication policies.

Large-scale retailers able to generate profit while taking into account sustainability should always pay particular attention to people, such as employees, consumers, and the community. In this regard, performance analysis of several large-scale retailers has revealed how much they focus on principles such as equal opportunities, fair pay, safety, health protection, training, enhancement, and involvement of employees.

Retailers' commitment to consumers is instead rooted in different types of policies such as the offer of affordable products, dedicated services (e.g. financial services), and the access to new products (e.g. pharmaceuticals, tourist services, fuel, etc.). Special attention is usually given to product safety, often attested by appropriate certification. Furthermore, it is standard practice for most of these companies to carry out many initiatives for the community; some of these are focused on consumption awareness, actions and projects of local and global development and solidarity, and the sale of fair trade products.

Regarding the environment, the analysis of large-scale retailers reveals a high commitment from the distributors themselves in developing processes, activities, products, and services to minimize negative impacts on the environment. 


\section{Environmental Sustainability in Large-Scale Retailers}

In the international and national arena, there are several examples regarding environmental policies implemented $d$ by large-scale retailers; some of these policies can be grouped into the following categories:

- Business functions. These policies are aimed to manage resources dedicated to logistic and other functions in a sustainable way. Specifically, they deal with waste reduction, recycling, conservation of energy and natural resources used for logistics activities (e.g. warehousing, storage, and transport) or other functions such as pre, during, and after sale services (e.g. home delivery), and the production and management of private labels.

- Eco-design and sustainable construction of stores, buildings, and points of sale. Many large-scale retailers have developed their structures according to new construction techniques and technologies to minimize the consumption of natural resources during the life cycle of the building. These buildings are often built taking into account various environmental aspects such as the impact of the structure on the local territory, the use, management, and disposal of water, the use of renewable or alternative energy, the control of building energy performance, and the choice of eco-friendly materials.

- Supply chain relationships for the development and management of eco-friendly and sustainable market offerings. Large-scale retailers, acting as intermediaries between manufacturers and end users, can promote, through their policies, environmentally friendly behaviors along the entire value chain, including suppliers and customers. For instance, sustainable assortment management engages not only those suppliers obliged to respect the environment during the development and management of their products and those of the retailers, if they manufacture private label products, but also those customers that by purchasing eco-friendly products become the targets of the retailers' green marketing policies. In this regard, many retailers, in recent years, have increased the number of eco-conscious product lines on their shelves, including the development of green lines in private labels. Among the most important ones, we find:

- Biological products, which combine techniques of cultivation and breeding that reduce the environmental impact. In particular, these manufacturing protocols avoid all synthetic chemicals and genetically modified organisms besides minimizing the use of natural resources and energy.

- Ecological products. These products usually refer to specific items dedicated to personal hygiene and house care (e.g. detergents, light bulbs, tissues, paper towels, etc.) with a low environmental impact.

- Zero km products. They refer to products provided by local producers whose manufacturing plants are generally located near the point of sale. This close proximity allows energy savings and lower $\mathrm{CO}_{2}$ emissions.

- Sold-in-bulk products. Bulk products are generally sold by means of dispensers placed at dedicated corners of the store and, as a result, they lack packaging whose disposal may cause pollution.

These green lines are increasingly present in several product ranges that make up the assortment of large-scale retailers. Some companies have also introduced, mainly for private label products, eco-friendly and sustainable 
packaging, also known as green packaging, which minimizes pollution and, at the same time, send a clear message to the consumers about the company's commitment to the environment. The management of green assortments is often certified by voluntary certification such as the Ecolabel certification, the standard Eco-Management and Audit Scheme (EMAS), and the Environmental Product Declaration (EPD).

- Other initiatives aimed at fostering environmental awareness include training courses on environmental issues for employees or other subjects, collaborations with schools or other training institutes, and implementation of projects, events or other activities related to environmental protection.

When it comes to tangible eco-friendly activities developed by Italian largescale retailers, it is possible to divide them into three distinct categories: 1) waste, 2) resources, and 3) goods handling.

1) With regard to waste minimization, our survey shows that the majority of Italian large-scale retailers have taken appropriate measures concerning: a) the development of promotional offers on expiring products, which are often displayed in prime merchandising areas inside the store; b) packaging reuse programs, especially for private label products; c) trade-in incentive campaigns; d) building customer awareness on how to reuse unused products or correctly identify the expiration date; e) enabling consumers to buy products in bulk or dispenser containers, especially when dealing with private label products; and e) recycling of unsold and/or faulty non-food products.

2) With regard to saving resources, the most common initiatives developed by large-scale retailers mainly refer to three areas: a) energy consumption, b) renewable energy, and c) water consumption.

a) Most of the retailers analyzed have actively pursued energy efficiency policies and consumption of renewable energy; among the various solutions pertaining to renewable energy resources, we find the implementation of solar, photovoltaic and thermal panels, the use of energy deriving from hydroelectric and wind plants, and the use of biomass. For what concerns the reduction in energy consumption, the main initiatives are aimed at improving the heating/cooling system efficiency of retailers' stores and buildings, the use of fluorinated gas-free refrigeration equipment, the replacement of conventional lighting systems with LED lighting solutions, the closure with sliding windows of horizontal and vertical refrigerated display cabinets, the adoption of electronic valves for the optimization of the temperature of such cabinets, and the presence of automated door opening and closing systems at the store entrance and exit.

b) Regarding water consumption, retailers' actions are oriented, on the one hand, to the rationalization of water consumption and, on the other hand, to the reuse of filtered wastewater. As for water consumption, companies have adopted monitoring systems and techniques to rationalize water consumption (e.g. the assessment of water consumption per square meter); as for filtered wastewater usage, many retailers are equipped with tanks for the collection of rainwater, which is then used for irrigation of green areas, fire-fighting systems, toilets, and more generally for all nondrinking water purposes. 
3) Most of the retailers surveyed have also made adjustments to their policies concerning the handling of goods in order to reduce the environmental impact of their business operations. This comprises a wide range of actions aimed at optimizing routes, maximizing the saturation of loads, and using low environmental impact vehicles.

\section{Environmental Sustainability in Carrefour}

The Carrefour Group, the leader among large-scale retailer in Europe and the second worldwide (by revenues), is a multi-local, multi-format, and omni-channel retailer operating in more than 30 countries - the three largest markets where it operates are Europe, Latin America, and Asia - with 12,300 stores generating, in 2017, a sales volume of 88.4 billion euros (VAT included) (www.carrefour.com).

In Italy, the Group operates with 1,071 points of sale spread over 18 different regions, employing over 20,000 people, and offering a wide range of brand products with over 3,000 items encompassing the various product categories proposed (www.carrefour.it).

The Group is strongly committed to sustainable development and CSR policies aimed at (www.carrefour.it):

- protecting biodiversity and the natural environment;

- building partnerships with suppliers;

- protecting human rights;

- offering safe and high quality products;

- motivating all Carrefour employees;

- developing local relations;

- complying with Italian law and regulations;

- achieving full transparency.

Some of the environmental sustainability initiatives put in place by the Carrefour Group in Italy can be divided into the same three distinct categories as those mentioned in the previous section: 1) waste, 2) resources, and 3) goods handling.

1) With regard to waste, for years Carrefour has implemented an anti-waste policy, adopting solutions for the reduction, management, and exploitation of waste in the various territories where it operates. In order to reduce waste, the Group has, for instance, modified its handling of goods packing by introducing reusable transport packaging, which is more robust and therefore more durable. For example, in 2016, Carrefour moved 500,000 plastic pallets and delivered 21,500,000 parcels of goods packed with reusable transport packages.

As for waste generated by business activities, taking into account the characteristics of the waste (e.g. organic material, special materials/ substances, paper / cardboard / wood, iron, plastic, etc.) and those of the point of sale, Carrefour has come up with various solutions for the collection, transportation, disposal, and valorization of the waste itself aimed at reducing its environmental impact. For example, all paper, cardboard, and other packaging materials, before being disposed, are pressed or compacted directly at the point of sale, thereby reducing the overall transport volume and the number of trucks needed to move it to the recycling plants, with a net positive effect in terms of environmental sustainability. In addition, paper, cardboard, 
and plastic packaging, as well as wood and iron, are all sent for recovery and recycling. Furthermore, organic waste is fully valued as it is sent to composting or recovery plants for biogas production. Even undifferentiated waste is valued, with over $80 \%$ of it being used to produce refuse-derived fuel.

Carrefour has also fostered consumer awareness of waste reduction and recycling practices. In this regard, the Group has developed practical solutions aimed at promoting separate waste collection; with regard to private label products, for example, consumers are given clear instructions on how to separate the different materials that make up the packaging and dispose of the same. In addition, the Group has set up in all its stores collection areas for non-used electrical and electronic devices as well as batteries collection boxes and used oil containers.

2) As far as resources are concerned, the Group has developed initiatives in line with those aforementioned, concerning the following three categories: a) energy consumption, b) renewable energy, and c) water consumption.

a) As for energy consumption, Carrefour's activities rely on technological modernization and optimization of lighting systems, implementation of heating and cooling systems, and constant monitoring of energy consumption. For example, with regard to lighting, the Group has installed lighting control systems in all its stores, warehouses, and offices using external brightness sensors able to modulate the energy consumption of the system according to the intensity of the natural light. Carrefour has also replaced fluorescent light tubes and metal halide light bulbs with LED lamps, thereby reducing energy consumption by $70 \%$. In refrigerated cabinets, traditional light bulbs have been replaced with long-lasting fluorescent heat lamps, with a $20 \%$ decrease in power consumption. In these refrigerated cabinets, thermal glass and sealing doors have also been installed to guarantee lower thermal dispersion. In addition, the Group has replaced HFC coolants with natural refrigerants in order to reduce energy consumption and environmental impact. In this regard, it is also worth mentioning the recovery of thermal energy from the refrigeration systems to be reused for heating purposes and hot water production. With regard to monitoring, measurement, evaluation, and analysis of energy consumption, the Group employs centralized technical management systems [i.e. building management system and environmental management system] that prevent excessive peaks of energy consumption and energy waste. Furthermore, the energy management system of Carrefour is certified according to the international standard of the International Organization for Standardization (ISO).

b) With regard to renewable energy special gas absorption heat pumps have been installed along with natural gas and aerothermal renewable energy; moreover, warehouses have been equipped with photovoltaic panels to produce electricity destined to logistics activities.

c) As for water consumption, the Group has developed a system to closely monitor water consumption and minimize water usage. For instance, all stores are equipped with special air-breaking devices that mix air and 
water, keeping the perception of liquids supplied to the end user unchanged.

3) Finally, regarding the handling of goods and the management of transport, the Group has committed itself to the goal of achieving greater efficiency by applying innovative solutions able to reduce $\mathrm{CO}_{2}$ emissions - in this regard Carrefour plans to achieve $40 \%$ reduction in $\mathrm{CO}_{2}$ emissions by 2025 and $70 \%$ by 2050 (compared to the year 2010).

In particular, regarding logistics, the tangible activities developed by the Group in terms of environmental sustainability include the optimization of the movement of goods between warehouses and points of sale, the saturation of loads to reduce transport volume, the combination of different modes of transport using eco-friendly hybrid electric trucks. In addition to intermodal transport, it is also worth mentioning the "Collaborative Logistics: Asset Sharing" program, which provides a framework for the sharing of transport vehicles between Carrefour and its supplier in order to optimize the return trip and reduce kilometers when trucks are running empty, thereby limiting $\mathrm{CO}_{2}$ emissions. Finally, in line with the initiatives aforementioned, Carrefour has expanded its fleet of full electric trucks for grocery delivery services; the Group has also been promoting sustainable customer mobility.

\section{Bibliography}

Ackerman, R.W. (1973). How Companies Respond to Social Demands, Harvard Business Review, 51 (4), 88-98.

Arrigo, E. (2003). Corporate Responsibility in Scarcity Economy. The Olivetti Case, Symphonya. Emerging Issues in Management (symphonya.unimib.it), (1), 114-134.

http://dx.doi.org/10.4468/2003.1.10arrigo

Bakos, Y. (2001). The Emerging Landscape for Retail E-Commerce, Journal of Economic Perspectives, 15 (1), 69-80. doi: 10.1257/jep.15.1.69

Bowen, H.R. (1953). Social Responsibilities of the Businessman, New York: Harper\&Row.

Brondoni, S.M., \& Mosca, F. (2017). Ouverture de 'Integrated Corporate Social Responsibility', Symphonya. Emerging Issues in Management (symphonya.unimib.it), (1), 1-6. http://dx.doi.org/10.4468/2017.1.01ouverture 1

Brondoni, S.M. (2012). Innovation and Imitation: Corporate Strategies for Global Competition, Symphonya. Emerging Issues in Management (symphonya.unimib.it), (1), 10-24. http://dx.doi.org/10.4468/2012.1.02brondoni

Brondoni, S.M. (2008). Market-Driven Management, Competitive Space and Global Networks, Symphonya. Emerging Issues in Management (symphonya.unimib.it), (1), 14-27. http://dx.doi.org/10.4468/2008.1.02brondoni 
Carroll, A.B. (2000). Ethical Challenges for Business in the New Millennium: Corporate Social Responsibility and Models of Management Morality, Business Ethics Quarterly, 10 (1), 33-42. https://doi.org/10.2307/3857692

Carroll, A.B. (1999). Corporate Social Responsibility: Evolution of a Definitional Construct, Business and Society, 38 (3), 268-295. https://doi.org/10.1177\%2F000765039903800303

Carroll, A.B. (1998). The Four Faces of Corporate Citizenship. Business and Society Review, 100-101 (1), 1-7. https://doi.org/10.1111/0045-3609.00008

Carroll, A.B. (1991). The Pyramid of Corporate Social Responsibility: Toward the Moral Management of Organizational Stakeholders, Business Horizon, 34 (4), $39-48$. https://doi.org/10.1016/0007-6813(91)90005-G

Carroll, A.B. (1979). A Three-Dimensional Conceptual Model of Corporate Social Performance, Academy of Management Review, 4 (4), 497-505. doi: $10.2307 / 257850$

Conad. (2015). Conad Annual Report.

Crane, A., Matten, D., \& Spence, L.J. (eds.) (2008). Corporate Social Responsibility: Readings and Cases in Global Context, London: Routledge.

Dahlsrud A. (2008), How Corporate Social Responsibility is Defined: an Analysis of 37 Definitions, Corporate Social Responsibility and Environmental Management, 15 (1), 1-13. https://doi.org/10.1002/csr.132

Davis, K. (1975). Five Propositions for Social Responsibility, Business Horizons, 18 (3), 19-24.

Davis, K. (1967). Understanding the Social Responsibility Puzzle: What does the Businessman Owe to Society?, Business Horizons, 10 (4), 45-50.

Davis, K., \& Blomstrom, R.L. (1966). Business and its Environment, New York: McGraw-Hill.

Deloitte. (2017). Global Power of Retailing. The Art and Science of Customers.

Eilbirt, H., \& Parket, I.R. (1973). The Current Status of Corporate Social Responsibility, Business Horizons, 16 (4), 5-14. https://doi.org/10.1016/0007-6813(73)90043-8

Elkington, J. (1997). Cannibals with Forks: The Triple Bottom Line of 21st Century Business, Oxford: Capstone Publishing Ltd.

Frederick, W.C. (1998). Moving to CSR4. What to Pack for the Trip, Business \& Society, 37 (1), 40-59.

Frederick, W.C. (1994). From CSR1 to CSR2: the Maturing of Business and Society Thought, Business \& Society, 33 (2), 150-164. https://doi.org/10.1177\%2F000765039403300202

Frederick, W.C. (1986). Toward CSR3: Why Ethical Analysis is Indispensable and Unavoidable in Corporate Affairs, California Management Review, 28 (2), 126141. https://doi.org/10.2307\%2F41165190

Frederick, W.C. (1960). The Growing Concern over Business Responsibility, California Management Review, 2 (4), 54-61. https://doi.org/10.2307\%2F41165405 
Freeman, R.E., \& Dmytriyev, S. (2017). Corporate Social Responsibility and Stakeholder Theory: Learning From Each Other, Symphonya. Emerging Issues in Management (symphonya.unimib.it), (2), 7-5. http://dx.doi.org/10.4468/2017.1.02freeman.dmytriyev

Freeman E. (2010). Strategic Management: A Stakeholder Approach, Cambridge University Press.

Freeman E. (1984). Strategic Management: A Stakeholder Approach, Cambridge University Press.

García-Sánchez, I.M., \& Noguera-Gámez, L. (2017). Integrated Reporting and Stakeholder Engagement: The Effect on Information Asymmetry, Corporate Social Responsibility and Environmental Management, 24 (5), 395-413. https://doi.org/10.1002/csr.1415

Gnecchi, F. (2009). Market-Driven Management, Market Space and Value Proposition, Symphonya. Emerging Issues in Management (symphonya.unimib.it), (2), 33-45. http://dx.doi.org/10.4468/2009.2.04gnecchi

Heald, M. (1957). Management's Responsibility to Society: The Growth of an Idea, The Business History Review, 31 (4), 375-384. https://doi.org/10.2307/3111413

Henderson, H., (1968). Should Business Tackle Society's Problems?, Harvard Business Review, 46 (4), 77-85.

Henriques, A., \& Richardson, J. (eds.) (2004). The Triple Bottom Line: Does it All Add Up?, London: Earthscan.

Javalgi, R., \& Ramsey, R. (2001). Strategic Issues of E-Commerce as an Alternative Global Distribution System, International Marketing Review, 18 (4), 376-391. https://doi.org/10.1108/02651330110398387

Johnson, H.L. (1971). Business in Contemporary Society: Framework and Issues, Belmont, CA: Wadsworth.

Jones T. (1980). Corporate Social Responsibility Revisited, Redefined, California Management Review, 22 (3), 59-67. https://doi.org/10.2307/41164877

Keijzers, G. (2002). The Transition to the Sustainable Enterprise, Journal of Cleaner Production, 10 (4), 349-359. doi: 10.1016/S0959-6526(01)00051-8

McGuire, J.W. (1963). Business and Society, New York: McGraw-Hill.

Perrini, F., Pogutz, S. \& Tencati, A. (2006a). Corporate Social Responsibility in Italy: State of Art, Journal of Business Strategies, 23 (1), 65-91.

Perrini, F., Pogutz, S. \& Tencati, A. (2006b). Developing Corporate Social Responsibility. A European Perspective, Cheltenham: Edward Elgar.

Riboldazzi, S. (2016). Corporate Governance and Sustainability in Italian LargeScale Retail Companies, European Scientific Journal, 12 (16), 1-23. doi: 10.19044/esj.2016.v12n16p1

Riboldazzi, S. (2015). Global Markets and Development Policies in Large-Scale Retailers, Symphonya. Emerging Issues in Management (symphonya.unimib.it), (5), 8-28.

http://dx.doi.org/10.4468/2015.5.02riboldazzi 
Riboldazzi, S. (2010). Retail Policies in the Global Gasoline Market, Symphonya. Emerging Issues in Management (symphonya.unimib.it), (1), 86-101. http://dx.doi.org/10.4468/2010.1.09riboldazzi

Riboldazzi, S. (2005). Global Retailers and Competitive Customer Value, Symphonya. Emerging Issue in Management (symphonya.unimib.it), (2), 77-87. http://dx.doi.org/10.4468/2005.2.07riboldazzi

Risso, M. (2010). Large Retailers' Financial Services, Symphonya. Emerging Issues in Management (symphonya.unimib.it), (1), 65-75. http://dx.doi.org/10.4468/2010.1.07risso

Salvioni, D.M. (2003). Corporate Governance and Global Responsibility, Symphonya. Emerging Issues in Management (www.unimib.it/symphonya), (1), 44-54.

http://dx.doi.org/10.4468/2003.1.05salvioni

Salvioni, D.M., \& Gennari, F. (2017). CSR, Sustainable Value Creation and Shareholder Relations, Symphonya. Emerging Issues in Management (symphonya.unimib.it), (1), 36-49. http://dx.doi.org/10.4468/2017.1.04salvioni.gennari

Sethi, S.P., (1975). Dimensions of Corporate Social Performance: An Analytical Framework, California Management Review, 17 (3), 58-64. https://doi.org/10.2307\%2F41162149

Steiner G. (1971). Business and Society, New York: Random House.

Wiese, A., Kellner, J., Lietke, B., \& Toporowski, W. (2012). Sustainability in Retailing - a Summative Content Analysis, International Journal of Retail \& Distribution Management, $40 \quad$ 318-335. https://doi.org/10.1108/09590551211211792 